DOI: $\underline{\text { https://doi.org/10.34069/AI/2021.45.09.19 }}$

How to Cite:

Konstantinovich, E.V., Mikhailovna, T.L., Dormidontov, R.A., \& Dolmatova, V.N. (2021). Assessment of the quality of inclusive education in general education organizations of Russia. Amazonia Investiga, 10(45), 185-197. https://doi.org/10.34069/AI/2021.45.09.19

\title{
Assessment of the quality of inclusive education in general education organizations of Russia
}

\section{Оценка качества инклюзивного образования в общеобразовательных организациях России}

Received: August 12, 2021

\section{Abstract}

The purpose of this work was an empirical study of assessing the quality of inclusive education in the regions of the Russian Federation. The article presents the results of monitoring the quality of the implementation of inclusive education in general educational organizations of the regions of the Russian Federation. The criteria for a comprehensive assessment of the quality of inclusive education are highlighted. Discrepancies in assessments of the quality of individual parameters of inclusive education in the regions were revealed, ways of increasing its effectiveness were outlined.

Key words: monitoring the quality of inclusive education, structural and psychological and pedagogical components of the quality of inclusive education, quality criteria.
Accepted: September 20, 2021

Written by:

Eliseev Vladimir Konstantinovich ${ }^{74}$ https://orcid.org/0000-0002-7607-911X

E-Library ID: 317980

Lilia Mikhailovna Tafintseva ${ }^{75}$ https://orcid.org/0000-0001-7729-7656 E-Library ID: 828916

Roman Alexandrovich Dormidontov ${ }^{76}$ https://orcid.org/0000-0002-3464-7086 E-Library ID: 839226

Vera Nikolaevna Dolmatova ${ }^{77}$ https://orcid.org/0000-0001-9590-0826 E-Library ID: 828388

\begin{abstract}
Аннотация
Целью настоящей работы выступило эмпирическое исследование оценки качества инклюзивного образования в регионах Российской Федерации. В статье представлены результаты мониторинга качества реализации инклюзивного образования в общеобразовательных организациях регионов Российской Федерации. Выделены критерии комплексной оценки качества инклюзивного образования. Выявлены расхождения в оценках качества отдельных параметров инклюзивного образования в регионах, намечены пути повышениях его эффективности.
\end{abstract}

Ключевые слова: мониторинг качества инклюзивного образования, структурные и психолого-педагогические компоненты качества инклюзивного образования, критерии качества.

The study was carried out with the financial support of the Ministry of Education of the Russian Federation as part of the execution of the state task for research, scientific project: "Psychology and Pedagogy of Inclusive Education: Assessment of the Quality of Inclusive Education in General Educational Organizations of Russia".

Agreement No. 073-03-2021-017 / 2 dated July 21, 2021

${ }^{74}$ Doctor of Sciences in Pedagogy, Professor Lipetsk State Pedagogical University named after P.P. Semenov-Tyan-Shansky Lipetsk, Russia.

75 D.Sc. in Pedagogic Science, Associate Professor Lipetsk State Pedagogical University named after P.P. Semenov-Tyan-Shansky Lipetsk, Russia.

76 D.Sc. in Pedagogic Science, Associate Professor University named after P.P. Semenov-Tyan-Shansky Lipetsk, Russia.

77 D.Sc. in Pedagogic Science, Associate Professor University named after P.P. Semenov-Tyan-Shansky Lipetsk, Russia. 


\section{Introduction}

Despite a sufficient number of publications devoted to the problems of inclusive education in the Russian Federation, conferences held at the international and all-Russian level on this topic, the problem of assessing the quality of the inclusive process in general education schools is still relevant. On the one hand, it is worth noting the scarcity of fundamental scientific research in this area of education. The content of the overwhelming majority of articles in scientific journals in the field of assessing the quality of inclusive education is superficial and descriptive. On the other hand, some experience has already been accumulated in monitoring and assessing the quality of inclusive education, both at the level of educational organizations and at the regional level. The generalization of this experience is a necessary condition for the formation of a comprehensive system for assessing the quality of the implementation of inclusive education, both in individual constituent entities of the Federation and at the federal level. Scientific research published by Russian scientists devoted to the problem of monitoring and assessing the quality of conditions for students with special needs and disabilities can be conditionally divided into two large groups: assessing the quality of the provided conditions for the implementation of inclusive education and analyzing the dynamics of indicators of the quality of inclusion. At the local level, in the conditions of the municipal educational system, the criteria and indicators of the effectiveness of the implementation of inclusive education can be: consultative, organizational and methodological support of inclusive education; the presence of a two-tier system with a base institution as a resource center, preparing teachers for work in inclusive education through the organization of advanced training and retraining courses for faculty and school teachers, meeting the educational needs of children with special needs and their parents, variability of education, increasing the inclusive competence of educators. The research problem consists, in our opinion, in the presence of contradictions between the quality indicators of the organizational, technological and methodological components of support for the implementation of inclusive education and the components of the educational process: personnel, material and technical and information education. However, the most obvious contradiction lies in the sphere of differences between qualitative indicators (indicators) of organizational, technological and methodological components of the infrastructure of inclusive education and its psychological and pedagogical components. Thus, the purpose of this work was an empirical study of a comprehensive assessment of the quality of inclusive education in the regions of the Russian Federation. The hypothesis of the study was the assumption that when assessing the quality of implementation of inclusive education in the regions of the Russian Federation, more attention is paid to such infrastructural components as: organizational, technological and methodological and, to a lesser extent, personnel, material, technical and informational psychological and pedagogical components of the quality of inclusive education even less often become an object of qualitative assessment in its structure. To test the hypothesis, the following research tasks were defined: summarize domestic and foreign research in the field of assessing the quality of the implementation of inclusive education and highlight its main criteria; conduct a monitoring study to assess the quality of implementation of inclusive education in the regions of the Russian Federation, based on the selected criteria; to summarize the data obtained based on the results of assessing the quality of inclusive education based on the selected criteria and to rank them; make a rating of regions based on an assessment of the quality of implementation of inclusive education.

\section{Literature review}

Scientific research of Russian scientists devoted to the problem of monitoring and assessing the quality of conditions for students with disabilities and disabilities can be conditionally divided into two large groups: assessment of the quality of the provided conditions for the implementation of inclusive education (Bogdanova \& Nazarova, 2020; Ilyina, 2019; Sheveleva, 2019) and analysis of dynamics indicators of the quality of inclusion (Alekhina, Melnik, Samsonova, Shemanov, 2019; Medova, 2013; Nizova, Danilova, 2017; Petrovich, 2020; Farman, 2012; Shemanov \& Samsonova, 2019). In most works devoted to the problem of assessing the quality of inclusive education, monitoring is most often indicated as a tool for assessing quality. In modern pedagogical conditions, monitoring is considered as one of the most effective tools for assessing the quality of inclusive education, with the help of which it is possible to identify and analyze changes in the inclusive process at all levels of education, taking into account various categories of children with special abilities and children with disabilities, forms of inclusions. In 


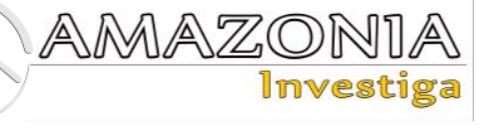

the list of criteria for assessing the quality of education of students of general secondary education institutions, they usually call resource (material and technical, educational, methodological, personnel and psychological support and socio-cultural environment), procedural (organization of the educational process, its content, methods, technology, means of teaching and upbringing) and productive ("the level of training and learning of the individual, the level of his upbringing and development, social adaptation and health status") groups of properties (Simaeva \& Khitryuk, 2014; Eliseev, Eliseeva, Korobova, Romanova, 2021). In the conditions of the municipal educational system, the criteria and indicators of the effectiveness of the implementation of the proposed model of inclusive education can be: consultative, organizational and methodological support of inclusive education; a two-tier system with a base institution as a resource center; preparing teachers to work in inclusive education through the organization of refresher courses and retraining for faculty and school teachers; meeting the educational needs of children with special needs and their parents; variability of education, increasing the inclusive competence of educators (Medova, 2013). The objects of monitoring are often the quality of the infrastructure components of inclusive education, such as the regulatory framework and special software and methodological support aimed at the most effective integration of children with special needs into the educational and socio-cultural space of a comprehensive school. Another qualitative component is the content of the activities of all specialists involved in the process of inclusion. Finally, it is impossible to achieve the most optimal qualitative results without the presence of a system of diagnostic and control-assessment measures that allow timely identification of the difficulties of students with disabilities and teachers working with them, as well as to trace the positive dynamics of the inclusive process in the educational organization.

The system for assessing the quality of the inclusive process in an educational organization, according to many Russian scientists: (Alekhina, Melnik, Samsonova, Shemanov, 2020; Bogdanova \& Nazarova, 2020; Petrovich, 2020; Ilyina,2019; Sheveleva, 2019; Vakorina, 2019) is aimed at identifying the levels of effectiveness of achieving goals when planning the results of integrating children with special needs into a mass school: how diverse are the forms of their implementation using modern psychological and pedagogical technologies, how high is the professional level of all participants in the educational process.

In some constituent entities of the Russian Federation, a procedure for assessing the quality of adapted basic educational programs (ABEP) has been introduced in accordance with the requirements of federal state educational standards for primary general education of students with special needs (Nizova \& Danilova, 2017). So, in the general educational organizations of the Chelyabinsk region, monitoring of the assessment of the quality of inclusive education was carried out, taking into account all categories of students' health disorders. As a result, the quality of the resource, personnel, financial and material-technical support of the ABEP was revealed and an invariant evaluation mechanism was developed, which makes it possible to most effectively track and evaluate the conditions for their implementation (Ilyina, 2019). The experience of the Novosibirsk region deserves attention, in which the emphasis in the implementation of inclusive education in the region is made precisely on the assessment of its quality. The purpose of the work of the international scientific school "Monitoring the effectiveness of inclusive practice" created at the Novosibirsk State Pedagogical University was to develop a methodological and criterial apparatus for monitoring the effectiveness of the educational process in conditions of inclusion. In the study conducted within the framework of the above school, emphasis was placed on the complex nature of assessing the quality of the results of an inclusive process, which implies an independent external assessment in the form of state final attestation (state final examination), and internal assessment (current control and intermediate attestation), which makes it possible to include consumers of educational services in the assessment process (Ryapisov \& Ryapisova, 2016; Farman, 2012).

In foreign scientific studies, the main attention is paid mainly to psycho-logical and pedagogical indicators not so much of the quality of inclusive education, as to the criteria of its organization. However, when assessing the quality of inclusion, the criteria (indicators) of the infrastructure of inclusive education are practically not applied. Nevertheless, in the monograph "Quality Indicators for Inclusive Education" (Mishra, Priyadarshi \& Jangira \& Kapoor, Satish, 2018), indicators for assessing the quality of inclusive education are presented as the quintessence of specific practices that are summarized as a result of research and school 
experience in order to contribute to the development of inclusive learning for all students, including students with special needs. Indicators of this kind are called quality indicators. Quality indicators are conditionally divided into the following spheres (areas, factors) of activity, among which: the school management committee; school environment; responsibility and authority; admission policy for children; meeting (Council) on joint planning; inclusive curriculum; training practice; assessment and evaluation; individual student support; parent and family support; staff development; health and safety; medical service; food. In some foreign studies, the criteria (indicators) of the quality of the implementation of inclusive education are practically identified with the principles of inclusion. For children with special needs, the principle of inclusive education means that the educational environment must correspond to the diversity of the needs of students with disabilities (National Professional Development Center on Inclusion, 2011).

Assessment of the quality of inclusive education in some Spanish schools has a multi-dimensional structure. Quality inclusive education is defined by a combination of elements that must act simultaneously. These elements relate to two areas: school policy and practice on the one hand, and the human and physical resources available to them on the other hand. The most important and irreplaceable element (quality criterion) in the processes of inclusive education is building a culture of inclusiveness in the school (Calero \& Benasco, 2016). In some European educational institutions, special attention is paid to measuring the audience indicators of inclusive education based on cooperation, differentiation of curricula, teachers' sense of self-efficacy when working with students with special needs (Early Childhood Technical Assistance Center, \& National Center for Pyramid Model Innovations, 2020). In some European preschool institutions, for example in Finland, such criteria of inclusion are practiced as: emotional support and general emotional tone in the class; communication between teacher and students; sensitivity and responsiveness of the teacher to the needs of children, etc. (Pakarine, Lerkkanen \& Suchodoletz, 2020).

In the materials on the inclusion of British researchers, one can find the synthetic concept of "Index", which, apparently, can be correlated with a generalized analogue of the indicator of the quality of inclusive education. Key components of the Index are concepts such as "inclusiveness", "barriers to learning and participation", "resources to support learning and participation" and "support for diversity" (Jones, 1996; Booth \& Ainsco, 2002). Sometimes in the English-language scientific literature on the practical implementation of inclusive education, you can find such a concept as "Assessment of the quality of inclusive experience". This assessment includes the following components: staff support, accessibility of the physical environment, individualization, participation and involvement of children, contacts and relationships between adults and children, contacts and interactions between children (Wolery et al., 1995). To assess the quality of the educational process in inclusive education, it is often useful to use scales for assessing the quality of classes in inclusive preschool programs. One such instrument for assessing the quality of a teacher's work was the "Inclusive Class Profile" - a rating scale that can be used to assess the systematic practical work of a teacher in inclusive classrooms (Soucacou, 2010). The Canadian SpeciaLink Inclusion Principles Scale assesses the degree to which early learning programs have consciously adopted a set of principles reflecting a commitment to include all children in an inclusive education "community". This scale includes such parameters as the physical, accessible environment, equipment and materials, the role of the director, personnel support, etc. (Lero, 2010; Cate, Diefendorf, McCullough, Peters, \& Whaley, 2010; Irwin, 2009). Often, general or specific principles are presented as indicators of the quality of inclusive education: restructuring culture, policies and practices in schools so that they respond to the diversity of students in a given area; reducing barriers to learning and participation for all students, etc. The development of quality indicators for inclusive special education is linked to the provision of vision and guidelines for policies, procedures and learning strategies that will contribute to the provision of effective education for all children with special educational needs and disabilities (Sánchez, Rodriguez \& Sandoval, 2019). Sometimes there are scales for assessing the comfort zone of childcare providers when serving young children with disabilities in inclusive conditions of early childhood (Buysse, Wesley, Keyes, Bailey, 1996).

In the practice of some preschool educational institutions in the United States, implementing inclusive education, indicators of the quality of academic and social growth of students with and without special needs are being introduced, as well as mixed assessment methods are used that 


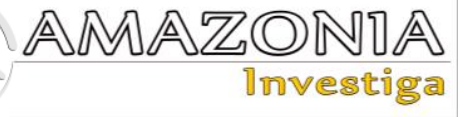

combine quantitative measurements of student development with a qualitative analysis of the views of parents, teachers and other school staff about child development within the program (Warren, Martinez \& Sortino, 2016). Often, schools that carry out inclusive education use self-assessment questionnaires of the quality of the educational process, which are necessary for the reflection of the teaching staff (Sulzberger, 2015).

Noteworthy is the Maine Quality Rating System (QRS) of the United States of America, called Quality for Me, which includes global programmatic metrics that define and improve quality in healthcare and education settings. This checklist expands on the current document with clear indicators that focus on evidence-based practices that promote inclusion of children with disabilities and different cultural and linguistic populations (Loreman, Forlin \& Sharma, 2014). In addition to inclusive education, the USA implements inclusive recreation programs. In the state of North Carolina, qualitative indicators (indicators) of such re-creative inclusive programs have been introduced: administrative support; the nature of the programs; Nature of activity; environmental / logistic considerations; programming methods.

\section{Materials and methods}

In the present study, monitoring was used as the main methodology for assessing the quality of implementation of inclusive education. In modern scientific research, including psychological and pedagogical, monitoring is considered as one of the most effective tools for assessing the quality of the infrastructure of the educational process (Sheveleva, 2019). The assessment of the quality of inclusive education was carried out according to 14 selected criteria during the monitoring of the official websites of educational institutions. The monitoring assessed the quality of implementation of inclusive education in 547 educational institutions of 12 constituent entities of the Russian Federation (from 40 to 50 for each constituent entity of the Russian Federation). The monitoring made it possible to assess the quality of the infrastructure components of inclusive education in the regions of the Russian Federation, i.e. how well the general educational organizations of the republics, territories and regions of Russia are equipped with a regulatory, material and technical, methodological base and special software and methodological support aimed at the most effective integration of children with special needs into the educational and socio- cultural space of a general education school, as well as identify the presence of an inclusive culture of teachers, students and their parents. The monitoring results made it possible to obtain an objective picture of the quality of the organization of the inclusive process in the educational institutions of the regions of the Russian Federation.

\section{State Hypotheses and Their Correspondence to Research Design}

The analysis of scientific literature on this issue allows us to emphasize the importance of the problem of assessing the quality of inclusive education. Research by Russian scientists is most often focused on the quality of the infrastructure components of inclusive education: the regulatory framework, special software and methodological support aimed at the most effective integration of children with special needs into the educational and socio-cultural space of a general education school. In foreign studies, one can observe a fairly wide range of indicators of the quality of inclusion, from "inclusive culture" to all kinds of "Indexes" of quality. On the other hand, an important component of assessing the quality of inclusive education for both Russian and foreign scientists is the content of the activities of all specialists involved in the process of inclusion. And, finally, the focus of research interests of both Russian and foreign scientists includes the quality of the system of diagnostic and control-assessment measures that allow timely identification of the difficulties of students with disabilities and teachers working with them, as well as to track positive dynamics of the inclusive process in the educational organization. It should be noted that the psychological and pedagogical component of assessing the quality of inclusive education in foreign studies is presented somewhat broader than in Russian, although it is more formalized.

Thus, the most obvious contradiction, in our opinion, is in the sphere of differences between the qualitative indicators of the organizational, technological and methodological components of the infrastructure of inclusive education and its psychological and pedagogical components, which is the main scientific problem of our research. The hypothesis of the study was the assumption that when assessing the quality of implementation of inclusive education in the regions of the Russian Federation, more attention is paid to organizational, technological and methodological and, to a lesser extent, to personnel, material, technical and information infrastructure components. Psychological and 
pedagogical components of the quality of inclusive education even less often become an object of qualitative assessment in its structure. Consequently, it is relevant to study a comprehensive assessment of the quality of inclusive education in the regions of the Russian Federation in order to obtain versatile information in order to qualitatively analyze the implementation of the principles and criteria for assessing this area in education.

In the light of the objectives of our research, we asked ourselves a research question: can the indicators of organizational, technological, methodological and other components of the infrastructure of inclusive education fully reflect its quality without taking into account the psychological and pedagogical component?

\section{Results}

The assessment of the quality of inclusive education was carried out according to 14 selected criteria in the course of monitoring the official websites of educational institutions. During the monitoring, the quality of implementation of inclusive education was assessed in 547 educational institutions of 12 constituent entities of the Russian Federation (from 40 to 50 for each constituent entity of the Russian Federation). The monitoring results are presented in Table 1 and Figure 1.

Table 1.

Results of monitoring the quality of inclusive education in the regions of the Russian Federation, according to the selected criteria (in\%)

\begin{tabular}{|c|c|c|c|c|c|c|c|c|c|c|c|c|}
\hline 州 & 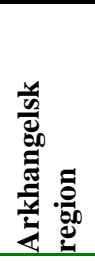 & 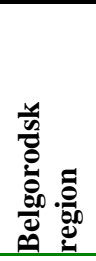 & 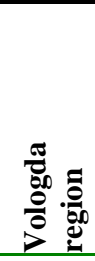 & 葼 & 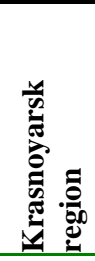 & 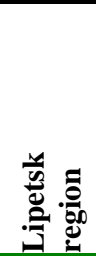 & 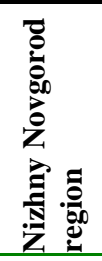 & 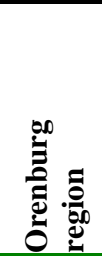 & 总 & 串串 & 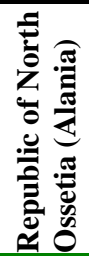 & 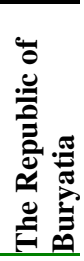 \\
\hline 1. & 100 & 100 & 10 & 100 & 100 & 100 & 100 & 100 & 100 & 90 & 42 & 100 \\
\hline 2. & 100 & 97 & 100 & 100 & 100 & 100 & 100 & 100 & 100 & 75 & 33 & 100 \\
\hline 3. & 81 & 64 & 82 & 75 & 87 & 86 & 81 & 54 & 93 & 46 & 46 & 78 \\
\hline 4. & 60 & 73 & 68 & 74 & 87 & 100 & 99 & 62 & 77 & 62 & 33 & 100 \\
\hline 5. & 67 & 66 & 83 & 25 & 25 & 80 & 67 & 44 & 57 & 67 & 25 & 64 \\
\hline 6. & 8 & 52 & 54 & 38 & 90 & 100 & 95 & 62 & 14 & 79 & 0,08 & 80 \\
\hline 7. & 25 & 14 & 58 & 11 & 4 & 90 & 91 & 29 & 50 & 70 & 6 & 83 \\
\hline 8. & 70 & 58 & 62 & 62 & 45 & 96 & 82 & 38 & 40 & 73 & 32 & 88 \\
\hline 9. & 50 & 63 & 39 & 61 & 61 & 100 & 76 & 48 & 54 & 75 & 20 & 81 \\
\hline 10. & 21 & 11 & 51 & 9 & 22 & 67 & 82 & 56 & 42 & 71 & 0,1 & 77 \\
\hline 11. & 31 & 79 & 47 & 78 & 87 & 99 & 88 & 42 & 68 & 85 & 75 & 94 \\
\hline 12. & 22 & 27 & 43 & 26 & 8 & 97 & 33 & 7 & 5 & 67 & 12 & 64 \\
\hline 13. & 33 & 43 & 53 & 30 & 8 & 99 & 3 & 0,1 & 7 & 87 & 0,1 & 95 \\
\hline 14. & 91 & 49 & 90 & 67 & 54 & 77 & 83 & 44 & 53 & 71 & 53 & 52 \\
\hline
\end{tabular}

Source: own authorship.

Quality criteria for inclusive education

1. Compliance of the adapted educational programs of inclusive education with the requirements of the Federal State Educational Standard for children with special needs.

2. Quality criteria for inclusive education.

3. Availability of pedagogical technology for the implementation of inclusive education

4. Methodological support of inclusive education

5. The system of special support for the development of the basic educational program by children in inclusive education.

6. Qualification of the staff of an educational organization participating in the implementation of inclusive education.

7. The quality of the staff of the educational organization involved in the implementation of inclusive education.

8. Material and technical support for the implementation of inclusive education and its levels.

9. Information support for the implementation of inclusive education.

10. Educational outcomes of students with special needs mastering an adapted 


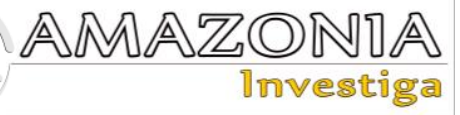

educational program of inclusive education.

11. Psychological and pedagogical readiness of teaching staff for inclusive education.

12. Psychological and pedagogical readiness of parents of children with special needs to implement inclusive education.

13. Psychological readiness of ordinary children for the conditions of inclusive education.

14. Staffing that implements the correctional orientation of training and an integrated approach to accompanying students from among persons with special needs and disabilities

According to the criterion "Compliance of adapted educational programs of inclusive education with the requirements of the Federal State Educational Standard for Children with Disabilities", only one constituent entity of the Russian Federation, namely the Republic of North Ossetia (Alania), recorded very low results compared to other regions (42\%), while in almost all other regions this result is $100 \%$.

According to the criterion "Organizational aspects of the implementation of inclusive education", this Republic is also in last place (33\%). In other constituent entities of the Russian Federation, high results of monitoring the quality of inclusive education were noted $(100 \%)$, with the exception of the Chita region (75\%).

Indicators of the criterion "Availability of pedagogical technology for the implementation of inclusive education" are also below the average in the Republic of North Ossetia (Alania) $-46 \%$. The same indicator is in the Chita region (46\%). For the rest of the RF subjects, the indicators are above average and high - in the range from $54 \%$ to $87 \%$.

North Ossetia (Alania) showed low indicators according to the criterion "Methodological support of inclusive education". The rest of the constituent entities of the Russian Federation showed higher indicators according to this criterion, in general, above the average level. Subjects such as the Republic of Buryatia and the Lipetsk region demonstrated $100 \%$ quality, the Nizhny Novgorod region $-99 \%$ quality, and the Krasnoyarsk region $-87 \%$ quality.

The lowest rates (25\%) according to the criterion "System of special support for mastering the basic educational program by children with inclusive education" were noted in the Irkutsk and Krasnoyarsk regions and the Republic of
North Ossetia (Alania). A low indicator was also noted in the Orenburg region. In the rest of the regions, this figure does not exceed $60 \%$, in the Lipetsk region it is higher $-80 \%$.

The lowest indicators according to the criterion "Qualification of the staff of the educational organization participating in the implementation of inclusive education" were noted in the Arkhangelsk region (8\%), Stavropol Territory (14\%), the Republic of North Ossetia (Alania) $(0.08 \%)$. The indicator is below average in the Irkutsk region (38\%). High rates were noted in Lipetsk region (100\%), Nizhny Novgorod region (95\%), Krasnoyarsk region $(90 \%)$. In other constituent entities of the Russian Federation, this indicator is higher than the average in the range from $52 \%$ to $78 \%$.

The regions showed rather low indicators according to the criterion "The quality of the staff of the educational organization participating in the implementation of inclusive education": The Republic of North Ossetia (Alania) $-6 \%$, Krasnoyarsk Territory - 4\%, Irkutsk region $11 \%$, Arkhangelsk region - 25\%, Nizhny Novgorod and Lipetsk regions $-90 \%$ each, other regions have indicators above average.

Low indicators according to the criterion "Material and technical support for the implementation of inclusive education and its levels" were noted in the Republic of North Ossetia (Alania) - 32\%, Stavropol Territory $40 \%$, Krasnoyarsk Territory $-45 \%$. High rates were noted in the Lipetsk region (96\%), the Republic of Buryatia (88\%), the Nizhny Novgorod region $(82 \%)$.

High indicators according to the criterion "Information support for the implementation of inclusive education" were noted in the Lipetsk region (100\%), Buryatia (81\%), Nizhny Novgorod $(76 \%)$, Chita region $(73 \%)$. The Republic of North Ossetia (Alania) - 20\%, the Vologda region $-39 \%$, the Orenburg region $48 \%$ demonstrated rather low indicators for this criterion.

Relatively high indicators according to the criterion "The results of education of students with disabilities mastering an adapted educational program of inclusive education" were shown by the Nizhny Novgorod region $82 \%$, Buryatia $-77 \%$, Chita region $-71 \%$. Very low rates were noted in the Republic of North Ossetia (Alania) - 0.1, Irkutsk region - 9\%, Belgorod region. 
High indicators according to the criterion "Psychological and pedagogical readiness of teaching staff for inclusive education" were recorded in the Lipetsk region (99\%), Buryatia (94\%), indicators below the average level - in the Arkhangelsk region - $31 \%$ ), Oren-burg region $42 \%$, Vologda region $-47 \%$.

Sufficiently high indicators according to the criterion "Psychological and pedagogical readiness of parents of children with disabilities to implement inclusive education" were recorded in Lipetsk region (97\%), Buryatia (64\%), Chita region $(67 \%)$. Very low rates were noted in the Orenburg region (7\%), Stavropol Territory (5\%), Krasnoyarsk Territory (8\%). In general, many regions showed low indicators for this criterion. Low indicators according to the criterion "Psychological readiness of ordinary children to the conditions of inclusive education" were recorded in the Orenburg region $(0.1 \%)$, the Republic of Ossetia $(0.1 \%)$, Nizhny Novgorod region (3\%). A high rate was noted only in the Lipetsk region (99\%) and in Buryatia (95\%). In general, the indicators for this criterion are extremely low.

High indicators according to the criterion "Staffing that implements the correctional orientation of training and an integrated approach to accompanying students from among people with disabilities and disabilities" were noted in the Vologda region (90\%), Arkhangelsk region (91\%), Nizhny Novgorod region (83\%). Indicators below the average level were recorded in the Belgorod region (49\%), the Orenburg region $(44 \%)$.

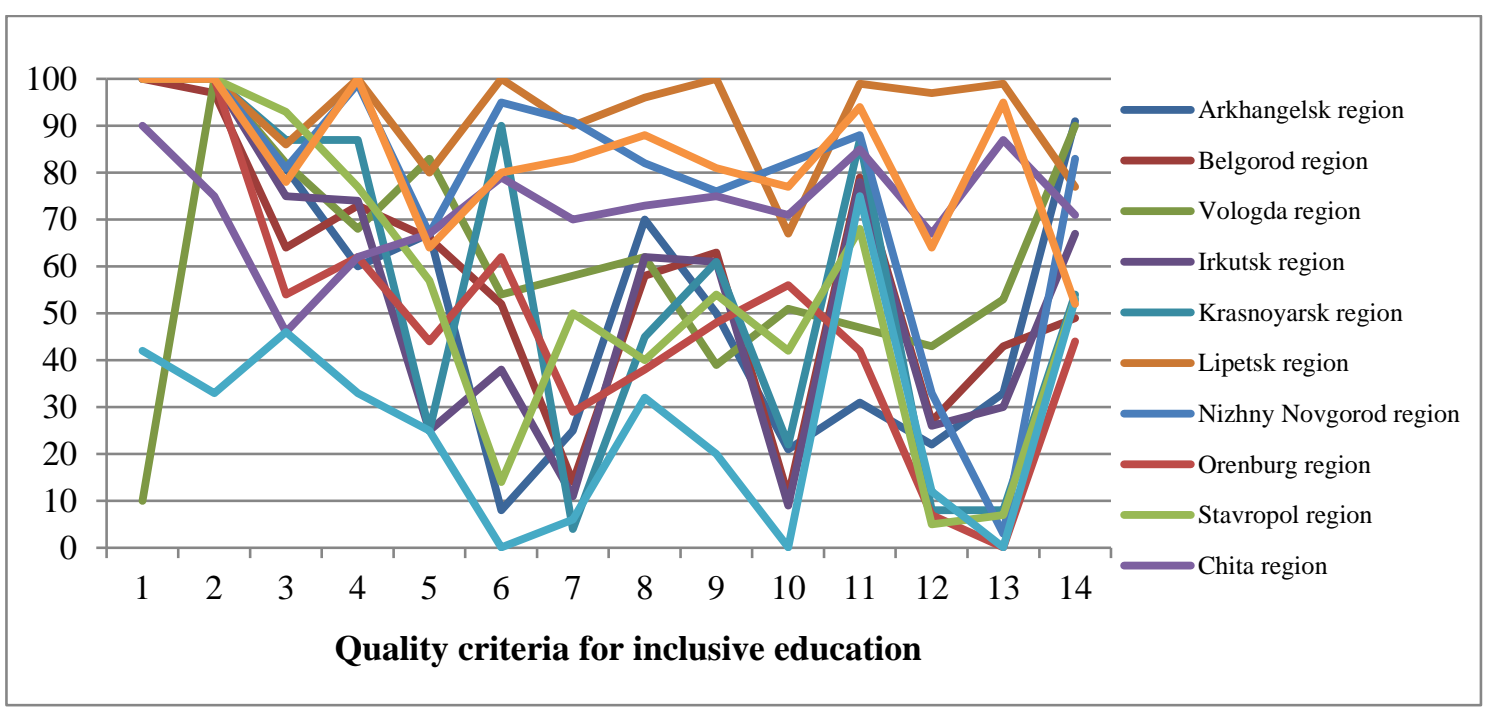

Source: own authorship

Figure 1. Assessment of the quality of implementation of inclusive education in the regions of the Russian Federation.

Quality criteria for inclusive education

15. Compliance of the adapted educational programs of inclusive education with the requirements of the Federal State Educational Standard for children with special needs.

16. Organizational aspects of the implementation of inclusive education.

17. Availability of pedagogical technology for the implementation of inclusive education

18. Methodological support of inclusive education

19. The system of special support for the development of the basic educational program for children in inclusive education

20. Qualification of the staff of the educational organization participating in the implementation of inclusive education

21. The quality of the staff of the educational organization involved in the implementation of inclusive education

22. Material and technical support for the implementation of inclusive education and its levels

23. Information support for the implementation of inclusive education

24. Educational outcomes of students with special needs mastering an adapted educational program of inclusive education 
25. Psychological and pedagogical readiness of teaching staff for inclusive education

26. Psychological and pedagogical readiness of parents of children with special needs to implement inclusive education

27. Psychological readiness of ordinary children for the conditions of inclusive education
28. Staffing that implements the correctional orientation of training and an integrated approach to accompanying students from among persons with special needs and disabilities

Table 2.

Rating of regions of the Russian Federation based on the results of monitoring the quality of inclusive education (average numbers in\%)

\begin{tabular}{lll}
\hline $\begin{array}{l}\text { № } \\
\text { I/II }\end{array}$ & Region name & $\begin{array}{l}\text { Average value of the overall indicator of } \\
\text { the quality of inclusive education }\end{array}$ \\
\hline 1. & Lipetsk region & $92,22 \%$ \\
2. & Rep. Buryatia & $82,57 \%$ \\
3. & Nizhny Novgorod region & $77 \%$ \\
4. & Zabaykalsky Krai & $72,72 \%$ \\
5. & Vologda region & $64,29 \%$ \\
6. & Belgorod region & $56,86 \%$ \\
7. & Krasnoyarsk region & $55,57 \%$ \\
8. & Stavropol region & $54,29 \%$ \\
9. & Arhangelsk region & $54,22 \%$ \\
10. & Irkutsk region & $54 \%$ \\
11. & Orenburg region & $49 \%$ \\
12. & Rep. North Ossetia (Alania) & $26,94 \%$ \\
\hline
\end{tabular}

Source: own authorship

\section{Discussion}

The data obtained as a result of monitoring the assessment of the quality of inclusive education in the regions of the Russian Federation (table 3) allow us to interpret them as follows.

In general, according to the monitoring results, the quality assessment of the main parameters of the implementation of inclusive education (material and technical, informational, personnel) is above the average level, which indicates a sufficient level of quality of the main infrastructural components necessary for the implementation of high-quality inclusive education in the regions of the Russian Federation. Nevertheless, there are significant discrepancies in assessments of the quality of individual parameters of inclusive education in the regions of Russia. In particular, the monitoring recorded significant differences in the results of assessing the quality of the psychological and pedagogical readiness of teaching staff for inclusive education $(72.75 \%)$ and the psychological readiness of parents of children with special needs $(43.08 \%)$ and ordinary children to inclusive education (38.18\%). The indicators of staffing, implementing the correctional orientation of training $(65.53 \%)$, its qualifications $(53.51 \%)$ and quality $(44.25 \%)$ differ. Significant differences were recorded between a high assessment of the quality of the organizational, technological and methodological components of supporting inclusive education (on average 80\%) and a low assessment of the quality of educational results of students with special needs who master an adapted educational program of inclusive education (42.43\%). An extremely low level of psychological readiness of ordinary children to the conditions of inclusive education $(38.18 \%)$ was noted, which indicates the unwillingness of most children to receive education in the same class and in the same educational environment together with children with special needs. 
Table 3.

Ranking indicators of the quality of inclusive education, based on the monitoring carried out in the regions of the Russian Federation according to the selected criteria (average values in\%)

\section{Rank The name of the criteria for the quality of inclusive education}

Average value

of quality

\begin{tabular}{|c|c|c|}
\hline 1 & $\begin{array}{l}\text { Compliance of adapted educational programs of inclusive education with } \\
\text { the requirements of the Federal State Educational Standard for children } \\
\text { with special needs }\end{array}$ & $94,33 \%$ \\
\hline 2 & Organizational aspects of the implementation of inclusive education. & $92,08 \%$ \\
\hline 3 & Methodological support of inclusive education & $74,58 \%$ \\
\hline 4 & $\begin{array}{l}\text { Availability of pedagogical technology for the implementation of inclusive } \\
\text { education. }\end{array}$ & $72,75 \%$ \\
\hline 5 & $\begin{array}{l}\text { Psychological and pedagogical readiness of teaching staff for inclusive } \\
\text { education }\end{array}$ & $72,75 \%$ \\
\hline 6 & $\begin{array}{l}\text { Staffing that implements the correctional orientation of training and an } \\
\text { integrated approach to accompanying students from among persons with } \\
\text { special needs and disabilities }\end{array}$ & $65,33 \%$ \\
\hline 7 & $\begin{array}{l}\text { Material and technical support for the implementation of inclusive } \\
\text { education and its levels }\end{array}$ & $62,17 \%$ \\
\hline 8 & $\begin{array}{l}\text { Material and technical support for the implementation of inclusive } \\
\text { education and its levels }\end{array}$ & $60,67 \%$ \\
\hline 9 & $\begin{array}{l}\text { The system of special support for the development of the basic educational } \\
\text { program by children in inclusive education }\end{array}$ & $55,83 \%$ \\
\hline 10 & $\begin{array}{l}\text { Qualification of the staff of the educational organization participating in } \\
\text { the implementation of inclusive education }\end{array}$ & $53,51 \%$ \\
\hline 11 & $\begin{array}{l}\text { The quality of the staff of the educational organization taking part in the } \\
\text { implementation of inclusive education }\end{array}$ & $44,25 \%$ \\
\hline 12 & $\begin{array}{l}\text { Educational outcomes of students with special needs mastering an adapted } \\
\text { educational program of inclusive education }\end{array}$ & $42,43 \%$ \\
\hline 13 & $\begin{array}{l}\text { Psychological readiness of ordinary children for the conditions of } \\
\text { inclusive education }\end{array}$ & $38,18 \%$ \\
\hline 14 & $\begin{array}{l}\text { Psychological and pedagogical readiness of parents of children with } \\
\text { special needs to implement inclusive education }\end{array}$ & $34,08 \%$ \\
\hline
\end{tabular}

Source: own authorship.

\section{Conclusions}

Analysis of research materials obtained in the course of monitoring the quality of implementation of inclusive education in the regions of the Russian Federation allows us to draw the following conclusions:

$\checkmark \quad$ The study summarizes data from the analysis of Russian and foreign studies related to the development of criteria for assessing the quality of implementation of inclusive education. The differences in approaches to the selection of criteria (indicators) of the quality of inclusive education are revealed. In Russian studies, researchers' attention is focused mainly on the quality criteria of the infrastructural components of the implementation of inclusive education: organizational, technological and methodological and, to a lesser extent, personnel, material, technical and informational. The psychological and pedagogical components of supporting inclusive education are not given due attention. Foreign scientific research uses criteria (indicators) for assessing the quality of inclusive education that differ in methodology and content: sociocultural, psychological and pedagogical, classroom criteria based on cooperation between teachers and children, differentiation of curricula, teachers' sense of self-efficacy when working with students with special needs and so on. Quality criteria for the infrastructure components of the implementation of inclusive education are used quite rarely.

$\checkmark \quad$ It is stated that there are differences between the indicators of the quality of 


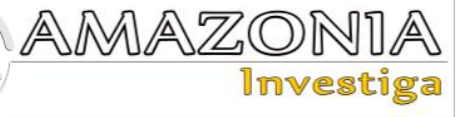

implementation of the organizational, technological and methodological components of supporting inclusive education in general educational organizations of the regions of the Russian Federation and indicators of the quality of the implementation of the components of ensuring the educational process: personnel, material, technical and information. However, the most significant differences are observed between the indicators for assessing the quality of implementation of the organizational, technological and methodological components of the infrastructure of inclusive education and indicators of the psychological readiness of parents of children with special needs and ordinary children to the conditions of inclusive education.

$\checkmark$ Monitoring research of a comprehensive assessment of the quality of inclusive education in the Russian Federation has shown that in Russian regions much more attention is paid to the quality of implementation of the organizational, technological and methodological and, to a lesser extent, personnel, material, technical and information infrastructure components of inclusive education. Much less attention is paid to the psychological and pedagogical components of the quality of implementation of inclusive education.

\section{Bibliographic references}

Alekhina S.V., Melnik, Yu.V., Samsonova, E.V., \& Shevmanov, A. Yu. (2020). Expert assessment of the parameters of the inclusive process in education. Clinical and special psychology, 9(2), (pp. 62-78): https://psyjournals.ru/psyclin/2020/n2/Alehi na_et_al_full.shtml

Alekhina, S.V., Melnik, Yu.V., Samsonova, E.V., \& Shevmanov, A. Yu. (2019). On the issue of assessing the inclusive process in an educational organization: a pilot study. Psychological and pedagogical research, 11(4). (pp. 121-132): https://psyjournals.ru/files/111073/psyedu_2 019_n4_Alekhina_Melnik_Samsonova_She manov.pdf

Bogdanova, T.G., \& Nazarova, N.M (2020). Evolution as a tool for managing the quality of inclusive processes in education. Special education, № 3, (pp. 24-39): https://cyberleninka.ru/article/n/evalyuatsiya -kak-instrument-upravleniya-kachestvominklyuzivnyh-protsessov-v-obrazovanii
Booth, T., \& Ainscow, M. (2002). Index for Inclusion. Developing Learning and Participation in Schools. CSIE. https://www.eenet.org.uk/resources/docs/Ind ex\%20English.pdf

Buysse, V., Wesley, P. W., Keyes, L., \& Bailey, D. B. (1996). Assessing the comfort zone of child care teachers in serving young children with disabilities. Journal of Early Intervention, $20, \quad 189-204$. https://www.rti.org/publication/assessingcomfort-zone-child-care-teachers-servingyoung-children-disabilities

Calero, J., \& Benasco, X (2016). “2 Quality factors of inclusive education in Europe: an exploration WORK TEAM". Quality factors of inclusive education in Europe: an exploration: https://includ ed.eu/sites/default/files/documents/quality_f actors_of_inclusive_education_final_en.pdf

Cate, D., Diefendorf, M., McCullough, K., Peters, M. L., \& Whaley, K. (Eds.). (2010). Quality indicators of inclusive early childhood programs/practices: A compilation of selected resources. Chapel Hill: The University of North Carolina, FPG Child Development Institute, National Early Childhood Technical Assistance Center. https://ru.scribd.com/document/436168801/q ualityindicatorsinclusion-pdf

Early Childhood Technical Assistance Center, \& National Center for Pyramid Model Innovations (2020). Indicators of HighQuality Inclusion. Retrieved from https://ectacenter.org/topics/inclusion/indicat ors.asp

Eliseev, V., Eliseeva, I., Korobova, M., \& Romanova, Ju. (2021) Assessing social cognitive functions in elementary school children: or problems of motor activity disorders. Revista Amazonia Investiga, 10(37), 125-134, DOI: 10.34069/AI/2021.37.01.13

Farman, I.P. (2012) Monitoring as a method of research and data presentation [Electronic resource] / I.P. Farman: - Access mode: http://cyberleninka.ru/article/n/monitoringkak-metod-issledovaniya-i-predstavleniyaznaniy

Ilyina, D.S. (2019) Monitoring of the Federal State Educational Standard of SPECIAL HEALTH NEEDS as an Assessment Procedure of Resource Support for the Implementation of Adapted Educational Programs. Scientific and methodological support for assessing the quality of education,

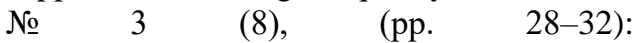
https://cyberleninka.ru/article/n/monitoringfgos-ovz-kak-otsenochnaya-protsedura- 
resursnogo-obespecheniya-realizatsiiadaptirovannyh-obrazovatelnyh-programm

Irwin, S. H. (2009). SpeciaLink Early Childhood Inclusion Quality Scale. Wreck Cove, NS: Breton Books. https://www.specialinkcanada.org/about/rati ng\%20scales.html

Jones, S.R. (1996) Toward Inclusive Theory, NASPA Journal, 33(4), 347-354, DOI: 10.1080/00220973.1996.11072421

Lero, D. S. (2010). Assessing inclusion quality in early learning and child care in Canada with the SpeciaLink Child Care Inclusion Practices Profile and Principles Scale. Retrieved from https://www.specialinkcanada.org/about/pdf/ SpeciaLink\%20Research\%20Report\%20on $\%$ 20Inclusion\%20Quality\%20Rating\%20Sc ale.pdf

Loreman, T., Forlin, C., \& Sharma, U. (2014). Measuring indicators of inclusive education: A systematic review of the literature. In Forlin, C., \& Loreman, T. (Eds.), Measuring inclusive education (pp.165-187). West Yorkshire: Emerald Group Publishing Limited.

https://www.researchgate.net/publication/28 6806003_Measuring_Indicators_of_Inclusiv e_Education_A_Systematic_Review_of_the Literature

Medova, N.A. (2013). Model of inclusive education in the conditions of the municipal educational system. 13.00.01 - General Pedagogy, History of Pedagogy and Education: Dissertation for the degree of candidate of pedagogical science. Tomsk, Tomsk State Pedagogical University, 285 p: https://viewer.rusneb.ru/ru/rs101005541733? page $=1 \&$ rotate $=0 \&$ theme $=$ white

Mishra, P. \& Jangira, N \& Kapoor, S. (2018). Quality Indicators for Inclusive Education [PDF file]. Retrieve from https://www.academia.edu/35259816/Qualit y_Indicators_for_Inclusive_Education_pdf

National Professional Development Center on Inclusion. (2011). Research synthesis points on quality inclusive practices. Chapel Hill: University of North Carolina, FPG Child Development Institute, National Professional Development Center on Inclusion. Retrieved from

http://npdci.fpg.unc.edu/sites/npdci.fpg.unc. edu/files/resources/NPDCI-

ResearchSynthesisPointsInclusivePractices2011_0.pdf

Nizova, L.M., \& Danilova M.I. (2017). Inclusive education as a form of socialization of disabled people (on the example of the Republic of Mari El). Educational policy, №
$1 \quad$ (75), (pp. 102-109):

https://elibrary.ru/download/elibrary_41442 546_56864602.pdf

Pakarine, E., Lerkkanen M.K. \& Suchodoletz, A. (2020). Teacher emotional support in relation to social competence in preschool classrooms, International Journal of Research \& Method in Education, 43(4), pp. 444-460. DOI: 10.1080/1743727X.2020.1791815

Petrovich, O.G. (2020). The system of monitoring studies of the learning conditions for persons with special health needs and disabilities: the experience of the Institute for the Development of Education. Bulletin of the Saratov Regional Institute of Education Development, № 1 (21), (pp. 33-41): https://www.elibrary.ru/item.asp?id=425652 58

Rojas-Bahamón, M.J., Aguilar-Cruz, P.J., \& Arbeláez-Campillo, D.F. (2020). Curricular integration as a strategy to strengthen the educational process in public institutions in COVID-19 times. Revista Inclusiones, 7(num Especial), pp. 233-241.

Ryapisov, N.A., \& Ryapisova, A.G. (2016). Monitoring the effectiveness of inclusive practice. Bulletin of the Novosibirsk State Pedagogical University, № 1 (29), (pp. 7-19) https://cyberleninka.ru/article/n/monitoringeffektivnosti-inklyuzivnoy-praktiki

Sánchez, S., Rodríguez, H., \& Sandoval, M. (2019). Descriptive and comparative analysis of School Inclusion through Index for Inclusion. Psychology, Society, \& Education, 11(1), $1-13$ https://www.researchgate.net/publication/33 2639467_Descriptive_and_comparative_ana lysis_of_School_Inclusion_through_Index_f or_Inclusion

Shemanov, A.Yu., \& Samsonova, E.V. (2019). Special education as a resource of inclusive educational process. Psychological Science and Education, 24(6), (pp. 38-46): https://psyjournals.ru/psyedu/2019/n6/Shem anov_Samsonova.shtml

Sheveleva, D.E. (2019). The quality of inclusive education: how the activity of the mass school in different countries is assessed. School technologies, № 4, (pp. 38-44): http://narodnoe.org/journals/shkolnietehnologii/2019-4/kachestvo-inklyuzivnogoobrazovaniya-kak-ocenivaetsya-deyatelnostmassovoiy-shkoli-v-raznih-stranah

Simaeva, I. N., \& Khitryuk, V. V. (2014). Inclusive educational space: SWOT-analysis. Bulletin of the Baltic Federal University, № 5, (pp. 31-39): https://cyberleninka.ru/article/n/inklyuzivno 


\section{AMAZONIA \\ Iกvestiำ}

e-obrazovatelnoe-prostranstvo-swotanaliz/viewer

Soucacou, E. P., \& Sylva, K. (2010). Developing observation instruments and arriving at interrater reliability for a range of contexts and raters: The early childhood environment rating scales. In Walford, G., Tucker, E., Viswanathan, M. (Eds.), The SAGE handbook of measurement (pp. 61-85). London, England: SAGE. https://www.researchgate.net/publication/29 2696338_Developing_observation_instrume nts_and_arriving_at_inter-

rater_reliability_for_a_range_of_contexts_a nd_raters_The_early_childhood_environmen t_rating_scales

Sulzberger, L.A., (2015) Quality Indicators for Inclusive Practices: How Are We Doing? Virginia Department of Education's. Retrieved from http://ttacwm.blogs.wm.edu/qualityindicators-for-inclusive-practices-how-arewe-doing/
Vakorina, L.Yu. (2019). Inclusive education in Russia: mechanisms of management and efficiency improvement: (dissertation. ... $\mathrm{PhD}$. in sociological) M., Peoples 'Friendship University of Russia, $221 \mathrm{p}$. https://www.dissercat.com/content/inklyuziv noe-obrazovanie-v-rossii-mekhanizmyupravleniya-i-povysheniya-effektivnosti

Warren, S., Martinez, R. \& Sortino, L. (2016) Exploring the Quality Indicators of a Successful Full-Inclusion Preschool Program. Journal of Research in Childhood Education, 30(4), 540-553, DOI: 10.1080/02568543.2016.1214651

Wolery, M., Gessler Werts, M., Lisowski, L., K. Caldwell, N., Snyder, E. (1995). Experienced Teachers' Perceptions of Resources and Supports for Inclusion. Education and Training in Mental Retardation and Developmental Disabilities. Division on Autism and Developmental Disabilities, 30(1), (pp. 15-26): https://www.jstor.org/stable/23879136 